\title{
The Effect of School Management and Teachers' Performance on the Effectiveness of Child-Friendly School at SMP Negeri 3 Kayuagung
}

\author{
Mediawati $\left.1^{*}\right)$, Bukman Lian², Mulyadi ${ }^{2}$
}

\author{
${ }^{1}$ SMP Negeri 3 Kayuagung \\ ${ }^{2}$ Universitas PGRI Palembang : drbukmanlian@univpgri-palembang.ac.id \\ *Corresponding Author. Email : mediawati775@gmail.com
}

\begin{abstract}
This study aimed to describe the significant influence of 1) school management on the effectiveness of a childfriendly school, 2) teacher performance on the effectiveness of a child-friendly school, and 3) simultaneous school management and teachers' performance on the effectiveness of a child-friendly school. The research method used in this study was the quantitative method, with a descriptive research design. The population and sample in this study were all teachers at SMP Negeri 3 Kayuagung, consisting of 47 individuals in total. The research data were obtained using a Likert scale questionnaire for all variables. The data were analyzed using the linear regression analysis technique. The results showed that 1.) school management did not have a major influence on the effectiveness of child-friendly school at SMPN 3 Kayuagung, 2.) teachers' performance had a great and significant influence on the effectiveness of child-friendly school at SMPN 3 Kayuagung, and 3) school management and teachers' performance simultaneously affected the effectiveness of child-friendly school at SMPN 3 Kayuagung. Based on multiple linear regression analysis, the sig value obtained was $0.033 \leq \alpha$ $(0.05)$.
\end{abstract}

Keywords: school management, teachers' performance, child-friendly school.

\section{INTRODUCTION}

The progress of a nation highly relies on human resources (HR). Education plays a very important role in the process of improving human resources, and education is the most influential factor in forming a high-quality generation to face the competitive situation in the era of globalization, especially in the areas of education and technology. Therefore, it is necessary to create progressive change and development in the education system.

The government has been working optimally in improving the quality of education, because with a good education system, it will be most likely that the future generation of the nation will be highly qualified in many expertises and adapting well as members of the society, as people of a state, and as parts of the global citizen. High-quality schools are usually referred to as educational institutions with great achievement records, high rates of academic success, effectiveness in many aspects, and a high level of excellence.

A school is one of the places where students obtain formal knowledge. Apart from being a place to learn academically, school is also a place where students gather with friends, play, and share happiness among them, so they are involved in good interactions. A school is also a place where teaching and learning activities take place and where interactions between teachers and students occur.

A school is a formal institution having the mandate to carry out a systematic and continuous process of education and learning. Teachers and education personnel in schools are expected to provide education and learning that can facilitate students to behave in a well-educated manner, which is shown in the form of academic achievement, ethical behavior and noble character, and high learning motivation.

All school members, especially principals and teachers, still have to continue to raise awareness that the school as a social system is a dynamic organization as a place for empowering students.

Bukman emphasized that schools should be able to provide safety and comfort for their students to pursue education. [1] They should be treated well by educators, because children who are learning are in the process of changing from bad to good, from ignorance to knowledge, and from immoral to moral. 
Creating an effective school is very difficult to conduct without knowing the purpose and function of the school, but it can be interpreted as a good school or an ideal school. The success of a school in achieving its goals or objectives is affected by the good quality teachers, inputs, and outputs of the school.

Based on the result of the preliminary observation made by researchers at SMP Negeri 3 Kayuagung, which is one example of a childfriendly school, it was found is that the comprehension of the concept of child-friendly school was still minimum. Moreover, the childfriendly school program was motivated by a misconception that put children as objects and teachers as ones who were always right, which could potentially cause bullying at schools/madrasahs. Based on KPAI data (20142015), $10 \%$ of cases of violence (physical, psychological, sexual, and neglect of children) were committed by teachers. Based on KPAI 2013 data, the most common occurrence of violence was bullying, as well as bad punishments, such as pinching (504 cases), yelling aloud (357 cases), and pulling students' ears (379 cases).

Physical violence occurring at schools is mostly committed by teachers. KPAI Commissioner, Retno Listyarti said violence perpetrated by educators usually took the form of physical punishments such as slapping, forcing students to stand in the sun, licking the toilet, doing push-ups and sit-ups, and smoking with a video recorder at the teachers' hands. According to Retno, the number of violence perpetrated by educators was quite high. This indicates that many educators do not prioritize the use of appreciation and affection towards students.

The initiative to create child-friendly schools cannot be separated from the program to develop child-friendly cities. One of the purposes of a childfriendly city program is for the fulfillment of 31 children's rights through the existence of childfriendly schools. A Child-friendly School program is an important indicator of the evaluation of childfriendly cities.

Moreover, the purpose of formulating a child-friendly school policy is to fulfill, guarantee and protect children's rights, as well as ensure that education units can develop children's interests, talents, and abilities and prepare them to be responsible for a life of tolerance, mutual respect, and work together for progress and the spirit of peace. Educational institutions are expected to not only create a future generation with high intellectual intelligence but also good emotional and spiritual intelligence.

Another factor that influences the effectiveness of child-friendly schools is teachers' performance. A teacher is o crucial component in the implementation of education. The teachers are the main actor who facilitates the implementation of a teaching and learning process compatible with a child-friendly school environment.

Based on the description above, the researchers are interested in conducting research with the title "The Effect of School Management and Teachers' Performance on the Effectiveness of Child-Friendly Schools at SMP Negeri 3 Kayuagung".

\section{METHODS}

This study used a quantitative descriptive method to reveal the partial effect of the existing variables (Sugiyono) [2]. The quantitative research variables tested in this study were school management (X1) and teacher performance (X2), school management (X1) on the effectiveness of child-friendly schools (Y), teachers' performance (X2) on the effectiveness of child-friendly school (Y), and simultaneous hypothesis testing of school management (X1) and teacher performance (X2) on the effectiveness pf child-friendly school (Y). All data obtained were processed by using quantitative analysis through the correlation (causal-effect) technique.

Correlational research aims to determine the existence of a cause-and-effect relationship that affects each other and is related to the research variables. The focus of this research was the effect of school management and teachers' performance on the effectiveness of a child-friendly school at SMP Negeri 3 Kayuagung.

\section{RESULTS AND DISCUSSION a. Description of School Management Data (Variable X1)}

School management (X1) leads and guides the school institution as an organization to achieve the vision and mission of the school and education in general. Operationally, school management is a process of optimization of school resources, such as teachers, funding, facilities, and others.

This study focuses on the school management process that has been carried out to develop a child-friendly school model at SMP Negeri 3 Kayuagung. 
Table 1

Overview of School Management Levels

\begin{tabular}{|c|c|c|c|}
\hline $\begin{array}{c}\text { Score } \\
\text { Range }\end{array}$ & Category & Total & Percentage \\
\hline$\geq 77$ & High & & $\%$ \\
\hline $9-77$ & Average & 7 & $00 \%$ \\
\hline$\leq 49$ & Low & & $\%$ \\
\hline
\end{tabular}

It is considered as being normal if the management carried out by school leaders is on the level of average, since the child-friendly school model is a new program implemented at SMP Negeri 3 Kayuagung. Four aspects of management are revealed through the questionnaire, they are 1) planning, 2) organizing, 3) controlling, and 4) directing. In the aspect of management, the organization and control need to be improved to create a high level of management.

\section{b. Teacher Performance Description (Variable X2)}

Performance is an effort made by a person or a group of people in an organization following their respective authorities and responsibilities to achieve the goals of the organization through a legal way, by not violating the law and is acceptable morally or ethically. Operationally, performance in research is an effort made by teachers to create a childfriendly atmosphere in a school.

Table 2

Categorization of Teachers' Performance

\begin{tabular}{|c|c|c|c|}
\hline $\begin{array}{c}\text { Score } \\
\text { Range }\end{array}$ & Category & Total & Percentage \\
\hline$\geq 77$ & High & & $\%$ \\
\hline $9-77$ & Average & 7 & $00 \%$ \\
\hline$\leq 49$ & Low & & $\%$ \\
\hline
\end{tabular}

Based on the data above, it can be concluded that teachers' performance is associated with the management that is not organized optimally. Lack of supervision and control can have an impact on teachers' performance, which is just on the level of average.

\section{c. Description of the Data of Child-Friendly School}

The child-friendly school (variable Y) is the implementation of education that focuses on creating a supportive learning community so that children can learn effectively in an atmosphere that provides a sense of security, appreciation, and encouragement The distribution of students' achievement data is presented in the following graphic.

Table 3

Categorization Of Child-Friendly Schools Score

\begin{tabular}{|c|c|c|c|}
\hline $\begin{array}{c}\text { Score } \\
\text { Range }\end{array}$ & Category & Total & Percentage \\
\hline$\geq 77$ & High & & $\%$ \\
\hline $9-77$ & Average & 7 & $00 \%$ \\
\hline$\leq 49$ & Low & & $\%$ \\
\hline
\end{tabular}




\section{Testing Data Analysis Requirements}

a. Normality test

The requirement for linear regression testing is that the data must have normality. The normality test is carried out to check the research data comes from a normal or abnormal distribution. The technique in testing normality used is the Kolmogorov-Smirnov formula with a significance level of 0.05 . The results of the normality test obtained using the SPSS 20 tool is presented in the following table.

Table 4

Normality Test Results

One-Sample Kolmogorov-Smirnov Test

\begin{tabular}{|c|c|c|c|c|}
\hline & & VAR_Y & VAR_X1 & VAR_X2 \\
\hline $\mathrm{N}$ & & 47 & 47 & 47 \\
\hline & Mean & 63.94 & 63.34 & 61.72 \\
\hline Normal Parameters & Std. Deviation & 5.223 & 3.726 & 4.302 \\
\hline & Absolute & .091 & .187 & .110 \\
\hline Most Extreme Differences & Positive & .091 & .131 & .098 \\
\hline & Negative & -.079 & -.187 & -.116 \\
\hline Kolmogorov-Smirnov Z & & .624 & 1.284 & .799 \\
\hline Asymp. Sig. (2-tailed) & & .831 & .074 & .540 \\
\hline
\end{tabular}

a. Test distribution is Normal.

b. Calculated from data.

The data distribution is considered normal when the significance value> 0.05. Based on the table above, the significance value of each variable is as follows: the School Management $=0.074$; Teachers' Performance $=0.546$; and Child Friendly Schools $=0.831$. The three variables have a significance $>0.05$ (with an error rate of $5 \%$ ). Therefore, it can be concluded that all variables are normally distributed, and can be put to linear regression test.

\section{Homogeneity Test}

Another requirement for research data to be put on the test of regression analysis is that the data are not heterogeneous. Therefore, the homogeneity test is carried out to know the level of similarity in several parts of the sample. It is conducted to ensure that the variance of samples taken from the same population is homogeneous. The variance in this study is the sample for the three research variables. If the significance value obtained is> from $\alpha=0.05$, it means that the research data is homogeneous. Homogeneity testing in this research was conducted by using SPSS 20, with the following results.

Table 5

Result of Homogenity Test

Test of Homogeneity of Variances

SCORE
\begin{tabular}{|c|c|c|c|}
\hline Levene Statistic & df1 & df 2 & Sig. \\
\hline 2.312 & 2 & 130 & .103 \\
\hline
\end{tabular}

Based on the data, all scores on the variables are from homogeneous samples. Sig value obtained is 0.103 , which is greater than $\alpha=0.05$. It means that Ho is rejected.

\section{Data analysis technique}

The data analysis technique used in this research is multiple linear regression. Multiple linear regression analysis is used to find the effect of two or more independent variables (school management and teachers' performance) on the dependent variable. Multiple linear regression was calculated using SPSS ver.20 program. The results of the linear regression analysis are presented in the table below. 
Table 6

Multiple Linear Regression Test Results Anova

\begin{tabular}{|c|c|c|c|c|c|}
\hline Model & Sum of Squares & $\mathrm{Df}$ & $\begin{array}{l}\text { Mean } \\
\text { Square }\end{array}$ & $\mathrm{F}$ & Sig. \\
\hline Reression & 179.52 & 2 & 89.761 & 3.673 & $.033^{b}$ \\
\hline Residual & 1075.28 & 44 & 24.438 & & \\
\hline Total & 1254.80 & 46 & & & \\
\hline
\end{tabular}

The level of the influence of the two variables on the child-friendly school can be seen from the model summary obtained from data processing using SPSS as follow:

b. Predictors: (Constant), VAR_X2, VAR_X1

Table 7

Summary Model of Regression Analysis

Model Summary

\begin{tabular}{|l|r|r|r|r|}
\hline Model & $\mathrm{R}$ & R Square & Adjusted R Square & Std. Error of the Estimate \\
\hline 1 & .378 & .14 & .104 & 4.944 \\
\hline
\end{tabular}

a. Predictors: (Constant), VAR_X2, VAR_X1

Based on the table above, R Square obtained is 0.143 . This means that the variables' contribution to school management and teachers' performance is only around $14.3 \%$. The rest of the percentage is other variables that are not included in this research. The information of the variable with the most influence on the effectiveness of childfriendly school implementation can be seen in the table below:

Table 8

Coefficients of Partial Regression

Coefficients

Coefficients $^{\mathrm{a}}$

\begin{tabular}{|c|c|c|c|c|c|c|}
\hline \multirow{2}{*}{\multicolumn{2}{|c|}{ Model }} & \multicolumn{2}{|c|}{ Unstandardized Coefficients } & \multirow{2}{*}{$\begin{array}{c}\text { Standardized } \\
\text { Coefficients }\end{array}$} & \multirow[t]{2}{*}{$\mathrm{t}$} & \multirow[t]{2}{*}{ Sig. } \\
\hline & & B & Std. Error & & & \\
\hline \multirow{3}{*}{1} & (Constant) & 37.610 & 13.44 & & 2.798 & .008 \\
\hline & VAR_X1 & .598 & .22 & .427 & 2.681 & .010 \\
\hline & VAR_X2 & -.188 & .19 & -.15 & -.973 & .336 \\
\hline
\end{tabular}

\section{Hypothesis Test}

In this study, the hypothesis offered was that school management and teachers' performance affected the effectiveness of child-friendly school at SMP Negeri 3 Kayuagung. The hypothesis testing was done using multiple linear regression formula assisted by using SPSS 20. The adopted hypothesis testing criteria are as follows:

a. If the significant value $\leq \alpha(0.05)$ or the coefficient F-count is significant at a level less than or equal to $5 \%$, Ho is rejected.

b. If significant $\geq \alpha(0.05)$, or the coefficient F-count is significant at a level of more than or equal to $5 \%$, Ho is accepted.

The results of regression testing using ANOVA showed a significance value of 0.033 . Based on the hypothesis criteria, if the significance is $\leq \alpha(0.05)$, it can be concluded that school management and teachers' performance simultaneously affect the effectiveness of a childfriendly school at SMPN 3 Kayuagung. The two variables $\mathrm{X}$ simultaneously affect variable $\mathrm{Y}$.

Based on the table above, the significance obtained for the variable of school management (X1) is 0.010 and the variable of Teacher Performance $(\mathrm{X} 2)$ is sig. 0.336. The test criteria used to determine the variables with a significant effect are as follows: 1) Ho is rejected if the significant value is $\leq \alpha(0.05)$. 2) Ho is accepted if the significant value $>\alpha(0.05)$.

Therefore, the teachers' performance variable is more influential than the school management variable because of sig. $\mathrm{X} 1=0.010$ $<$ from $\alpha$ (0.05). Meanwhile, the teacher 
performance variable is considered to have a significant effect, because of sig. X2 $=0.336>\alpha$ (0.05).

The linear regression equation obtained in this study based on the data in Table 19 above is as follows:

$$
\begin{aligned}
& \mathrm{Y}=\mathrm{a}+\mathrm{b} 1 . \mathrm{X} 1+\mathrm{b} 2 . \mathrm{X} 2 \\
& \mathrm{Y}=37.610+0.598 . \mathrm{X} 10.188 . \mathrm{X} 2
\end{aligned}
$$

\section{Discussion}

\section{The Effect of School Management and Teachers' Performance on the Effectiveness of Child- Friendly School}

The results of hypothesis testing show the significant value of multiple linear regression of 0.033. Based on the hypothetical criteria, if the significance is $\leq \alpha(0.05)$, it can be concluded that school management and teachers' performance simultaneously affect the effectiveness of a childfriendly school. However, if viewed from the partial analysis, the school management is less influential than the performance of teachers.

In their research, Kurniayawan and Sunandar explained that school management carried out in the implementation of effective childfriendly school is as follows:

a. Planning for child-friendly schools is carried out by making child-friendly school implementation indicators referring to eight national education standards during a meeting with all school authorities.

b. The organization of the child-friendly school is carried out by forming an organizing team which is consisted of the supervisor, the person in charge, the chief executive, the monitoring the implementation division, health and environmental division, coordination and socialization division, and the monitoring and evaluation division.

c. The implementation of a child-friendly school is carried out in outdoor classrooms which are carried out in the gazebo, middle yard, and around the school environment.

d. Supervision of a child-friendly school is carried out regularly and is carried out by all school authorities. Supervision activities are carried out with educational guidance, appeal, warning, socialization, and punishment.

e. The school principal plays a role in making the program structure, providing supporting facilities, making improvements to aspects that support child-friendly schools, and monitoring and evaluating the implementation of child-friendly school programs.

f. The teacher is in charge of making lesson plans based on the indicators of child-friendly school, guiding children with below-average abilities, providing and checking facilities available at schools, facilitating and motivating, assisting, and fostering the implementation of child-friendly school programs together with the principal.

g. Parents always support programs related to the child-friendly school. They also attend the socialization of child-friendly school programs organized by the school.

h. One of the external parties supporting the implementation of child-friendly school programs is the Ministry of Women's Empowerment and Child Protection (KPPPA). DSP3AP2KB in the division of Women's Empowerment and Child Protection has a role in providing socialization for the childfriendly school. [3]

As the school manager, The principal has an important role in improving managerial quality in the implementation of child-friendly schools. The results of research by Jahidin and Torro showed several roles of school principals in carrying out child-friendly school management, as follow:

a. As an educator. The principal as an educator is related to his role in formulating planning strategies, providing advice and encouragement to school members, and fostering the members of the school community including teachers, students, and other school staff to understand child-friendly school programs.

b. As a manager. Managing is a process of planning a strategy, instructing, and empowering members to achieve goals more effectively. The empowerment carried out by the principal can be in form of conducting socialization related to child-friendly school programs and holding meetings regarding child-friendly school. Also, the principals should involve the teachers in training held by the Office for Women's Empowerment and Child Protection to increase their knowledge of children's rights convection.

c. As an administrator. The school principal is creating an organization by selecting trained teachers as coaches for the selected students to participate. Furthermore, the principals need to do coordination by ensuring that school staffs work together in creating a successful childfriendly school program. Finally, the school principal should assign duties to teachers regarding the child-friendly school according to their expertise regarding children's rights.

d. As a supervisor. Supervision carried out by the principal is divided into two ways: directly and indirectly. Direct supervision is done by directly visiting school activities and activities, checking the school area, checking the cleanliness of the school, visiting classes, canteens, and other school areas. On the other hand, indirect supervision is conducted by monitoring through electronic media such as cellphones and CCTV.

e. As a leader. School principals carry out this function by providing directions and explaining instructions related to the procedure for 
implementing a child-friendly school to the member of the school community during the ceremonies or other events. This is in line with the principal's function as a leader who provides guidance and supervision, increase the willingness of education personnel, open twoway communication, and give tasks and responsibilities. [4]

\section{Challenges of Implementing a Child-Friendly School}

Tresiana argues that the most important thing in implementing a child-friendly school is making the school a safe and comfortable place for students. [5] The implementation of a child-friendly school does not mean building new schools but making sure that the existing school is a safe and comfortable place for everyone.

In research conducted by Utari, it was stated that the successful implementation of a ChildFriendly School is supported by the use of the Child-Friendly Teaching Model (CFTM) as the basis for compiling the curriculum. [6] The components of the CFTM include the 3Ps (Provision, Protection, and Participation). The descriptions of the three components are as follows:

1) Provision is the availability of the children's needs of love and affection, food, health, education, and recreation. The teachers fulfill the provision or show love and affection to all students in learning such as giving all the students the same opportunity, not differentiating from each other, giving care and compassion to all students in learning, creating an engaging learning activity for students, and providing equal time for everyone to take a rest.

2) Protection is the right to be protected from threats, discrimination, and punishment, both physical and psychological. Teachers protect students by paying attention to students' health, the environment, and safety in schools, protecting them from physical and psychological violence, harassment, and discrimination.

3) Participation is the right related to the right to act; in this situation, students are given the freedom to show opinions, ask questions, challenge the argument, and play an active role in the classroom and at school. The teachers stimulate students to be active in the classroom by giving them equal opportunities to do many activities. Students are also allowed to select a group they want to be in.

A simple implementation of classroom organization based on provision, protection, and participation is done when performing various seating arrangements. Teachers can manage students' seating in the class by paying attention to their conditions and learning styles. Another example is when organizing extracurricular activities, the data of student interests and talents are taken into account, by considering the guidance from the counseling teacher.

In the learning process, the implementation of problem-based learning by referring to provision, protection, and participation is carried out by paying attention to a different level of learners in receiving learning materials. The method of teaching is created by utilizing technology, such as LCD. Learning is designed to be interesting and fun so that students are active and willing to participate. Several studies have shown that local wisdom can be a good learning resource and stimulate student participation in learning.

The provision of remedial teaching for students with learning difficulties is not taken into practice. In the concept of children's school, students who experience learning difficulties, learning obstacles, and slow learning have the right to get additional learning. Apart from that, talented students should also be given special training to improve their skills.

To motivate teachers to take an active role in administering the child-friendly school, teachers must also understand violence awareness, and make it a belief that children should be protected against violence in schools. As long as there is high violence awareness among them, teachers' participation in the improvement of a child-friendly school will be highly effective.

Prevention of violence against children at school is pursued through school regulations in the form of written agreements started from the first day of school for the students that bind teachers and parents to pay more attention to children's needs, treat and protect them with either when they are at school or home. Besides, schools should adjust school regulations that support the fulfillment of children's rights and protection, and create a safe and comfortable environment.

The increase of confidence in the prevention of violence needs to be carried out by consistently carrying out socialization, guidance on antiviolence to all members of the school community, including the headmasters, teachers, students, parents, and school caretakers to support the implementation of a child-friendly school program.

Shaeffer (Rangkuti \& Maksum) argues that the capacity of a school to be child-friendly is directly related to the support, participation, and collaboration from students' parents and family at home. [7] The quality and intensity of communication between teachers, students, and parents should be improved so that there are no gaps in information, one of which is by opening up many channels of communication and good discussion through direct or indirect communication. 


\section{Teachers' Performance on the Development of Child-Friendly School}

The results of data analysis indicate that teachers' performance has an important role in the implementation of a child-friendly school. Teachers' Performance Variable (X2) has a sig. $0.336>\alpha(0.05)$. Teachers are the executors of the programs created and by the school. The teachers' lack of understanding of the implementation of child-friendly schools will make learning activities still vulnerable to violence against children. This is following the problems raised in this research problem.

Clair, Miske, \& Patel explained that teachers must understand the principles of a child-friendly school. Those principles are as follows:

1) Non-discrimination, by ensuring the opportunity for every child to pursue education without discrimination based on disability, gender, ethnicity, religion, and parental background;

2) The students' needs should always be the main consideration in all decisions and actions taken by the teacher concerning them.

3) Survival and development, by creating an environment that respects the dignity of the children and ensuring the holistic and integrated development of every student.

4) Respect the children's opinions, including respect for their right to express their perspectives in everything affecting them in the school environment.

5) Good management, by ensuring transparency, accountability, participation, accessibility of information, and the rule of law in educational units. [8]

Among the obstacles in implementing a child-friendly school by teachers is the difficulty to control teacher dominance in the learning process. Ratna and Torro explained that in a child-friendly school, teachers are not the only ones who decide everything during the learning, but students are also given space to play an active role and contribute to the physical arrangement of the school to create fun learning. [9]

Teachers' performance in creating a childfriendly school is not only through structuring the physical environment, but also the psychological aspect. Ngadiyo stated that child-friendly education is non-discriminative and adopting the concept of PAIKEM, which stands for Pembelajaran Aktif, Inovatif, Kreatif, Efektif dan Menyenangkan (Active, Innovative, Creative, Effective, and Fun Learning), caring for and protecting children, having a healthy environment, and inviting the participation of parents and the community. [10] Marcella (Jailani, Anggraini, and Rafiq) also explained that a child-friendly school should be able to facilitate children's needs equal to their potential. [11] It is not only the functional, rational, and economic needs of students to be fulfilled, but also their emotional expression and interaction with others.

Furthermore, a child-friendly school should avoid pressure, force, and intimidation to children so that they have the freedom to choose to learn and develop their potential with high excitement. Teachers should provide an example by giving students their rights to create regulation in the classroom and its consequences for breaking it, and create good relationships with students inside and outside the classroom.

The main teachers' role in implementing child-friendly school is integrating learning with child-friendly school indicators. Sudirjo explained the nuances of learning following the indicators of child-friendly school are as follows:

a. There is a learning process in such a way that students feel happy following the lesson, where there is no fear, anxiety, and anxiety. Students are active and creative and not feeling inferior competing with others.

b. There is an effective learning process resulting from the application of varied and innovative learning methods.

c. The teaching and learning process is supported by teaching media such as textbooks and other teaching aids to help students' understanding.

d. The teacher as a facilitator applies a cooperative and interactive teaching and learning process both individually and in groups.

e. There is a participatory learning process. Students have the enthusiasm to participate during the learning because the teacher as the facilitator encourages and facilitates them to find their way of answering a problem.

f. Students are involved in various activities that develop their abilities (learning by doing, practice, etc.). [12]

The implications of the concept of a nursery school for teacher competence are as follows:

1) The teachers observe the children's gradual growth and development

2) The teachers conduct consultations with the principal on the problems faced by children in the classroom

3) The teachers give attention in the form of affection for students

4) The teacher must recognize the children's personality well

5) Teachers provide opportunities for children to play

6) The ideal teachers have a cheerful personality

7) The teachers can interact well with other people, including students. 


\section{The aspects to consider in creating an effective child-friendly school}

Three aspects need to be considered by the school principals or managers to create an effective child-friendly school, they are:

(a) an appropriate school program;

(b) a supportive school environment; and

(c) adequate infrastructure.

\section{a. Appropriate school program}

School programs should be adapted to the children's world, which means that the program is adapted to their developmental stages. Children should not be forced to do something. The childfriendly school program creates an encouraging situation for students to explore themselves. An important factor that must be considered is the active participation of the students in the activities or programs at the child-friendly school.

Participation will increase when the activities meet the needs of the children. Leaders, teachers, and school staff must understand the characteristics and basic needs of students at each educational unit. For instance, in primary education, the school programs emphasize the function and learning process rather than prioritizing the learning outcomes. On the other hand, in secondary education, it is emphasized on the exploration and learning outcomes. Therefore, in the process of teaching and learning in junior and senior high schools, students are encouraged to create a product or have a complete understanding of a material concept.

The keyword from this aspect is that students should not be forced to do something, instead, it should be emphasized more on function, their active participation, love for them, understanding of the world of children, and having the right approach.

Abduh \& Zainudin explained that the teachers play an important role in the process of creating change in the classroom as well as in schools and education systems in general. [13]

The success of the child-friendly school model depends largely on teachers' involvement. In pedagogic competence, teachers need to know their students well personally, including understanding them by utilizing the principles of cognitive development, personality principles, and identifying their potential and learning resources. In personality competence, teachers must have authoritative personality behavior, including having a positive influence on students and behaving respectfully. Besides, classrooms are not just places where students learn academic subjects. It is a social context in which students learn social aspects, such as friendship, cooperation, and accepted behavior.

The preparation of child-friendly programs is associated with the process of children's development. Therefore, whatever the activities are, it is expected that they will not inhibit the development of children, whether they are related to physical, mental, or social development

\section{b. A supportive environment}

A supportive school environment is possible to create when the school atmosphere is supportive as a place for children to learn about life. School activities should focus on fun learning experiences, great values, and provide broad learning opportunities for students. The learning atmosphere created relates to cooperation, collaboration, and freedom of expression. A good school environment is very conducive to developing children's potential because they can express themselves freely according to their world. Also, keeping environmental cleanliness and accessibility to healthy drinking water are important factors for children's development.

Teachers must be able to develop a childfriendly environment, which means they must be aware of the rights and needs of students. Oluremi stated that teachers must have managerial abilities, such as: creating warm and lively teacher and student interactions, allowing students to actively participate in the teaching and learning process, encouraging students to work cooperatively in the classroom, speaking in a comfortable voice, using a good approach, and creating friendly relationships between the teacher and the students. [14] Every teaching activity cannot be separated from efforts to improve the learning atmosphere in a friendly and relaxing classroom condition.

\section{c. Adequate Facilities Infrastructure}

Adequate facilities and infrastructure are needed in support of children's learning needs. The infrastructure does not have to be expensive, but it must meet the needs of the children. Schools need to arrange an attractive, engaging, and impressive school environment and classrooms to make students comfortable and enjoy their time at school. Besides, schools must also guarantee the rights of the children to participate.

Schools should provide a means or media for creative education. Ideally, there are some facilities available at the school, such as an information center and creative and recreational facilities for children, classrooms, and school suggestion boxes, bulletin boards, and magazines or newspapers for students.

Teachers must also develop adequate school infrastructure, not only by managing buildings, tables, chairs, or other objects but also by utilizing learning media that are presented effectively for the learning process. In general, books are part of the infrastructure, but sometimes teachers have to think creatively and use contextual things, such as the nature around the school as one of the learning resources. 


\section{CONCLUSION}

Based on the findings and research hypothesis testing, it can be concluded that School management did not have a major influence on the effectiveness of a child-friendly school at SMP Negeri 3 Kayuagung. Teachers' performance had a great and significant influence on the effectiveness of a child-friendly school at SMP Negeri 3 Kayuagung. School management and teachers' performance simultaneously affected the effectiveness of a child-friendly school at SMP Negeri 3 Kayuagung.

\section{REFERENCES}

[1] Lian, B. (2020). Teacher's Model in Building Student's Character. Journal of Critical Reviews ISSN 2394-5125 Volume 7, Issue 14

[2] Sugiyono. 2014. Metode Penelitian Kuantitatif Kualitatif dan $R \& D$. Bandung: Alfabeta. PT Refika Aditama

[3] Kurniyawan, M. D., Sultoni, S., \&Sunandar, A. (2020). Manajemen Sekolah Ramah Anak. JAMP: Jurnal Administrasi dan Manajemen Pendidikan, 3(2), 83-89.

[4] Jahidin, U. H., \&Torro, S. (2020). Peran Kepala Sekolah Terhadap Sekolah Ramah Anak Di SMP Negeri Di Kota Makassar. Jurnal Sosialisasi: Jurnal Hasil Pemikiran, Penelitian dan Pengembangan Keilmuan Sosiologi Pendidikan, 73-80.

[5] Novita, T. (2018). Pelatihan Mendesain Kebijakan dan Strategi Sekolah Ramah Anak pada Satuan Pendidikan. Jurnal Pengabdian kepada Masyarakat volume 2, Issue 1 pages 41-48.
[6] Utari, R. (2016). Pengaruh Model Pembelajaran Explicit Instruction Berbantuan Lingkungan Alam Sekitar Terhadap Hasil Belajar IPA Siswa Kelas IV. Dalam E-Journal PGSD Universitas Pendidikan Ganesha.

[7] Rangkuti, S. R., \& Maksum, I. R. (2019). Implementasi Kebijakan Sekolah Ramah Anak Dalam Mewujudkan Kota Layak Anak di Kota Depok. Publik (Jurnal Ilmu Administrasi), 8(1), 38-52.

[8] Clair, N., Miske, S., \& Patel, D. (2012). Child rights and quality education: child-friendly schools in Central and Eastern Europe (CEE). European Education, 44(2), 5-22.

[9] Ratna, R., \&Torro, S. (2019). Impementasi Sekolah Ramah Anak di SMAN 3 Makassar. Jurnal Sosialisasi, 111-116.

[10] Ngadiyo. 2013. Homeschooling, Melejitkan Potensi Anak. Majalah Embun. Edisi 49-VRajab 1434 H/Mei 2013.

[11] Jailani, A., Anggraini, F. S., \& Rofiq, M. H. (2020). Model Pengembangan Karakter Disiplin Peserta Didik Melalui Sekolah Ramah Anak Di SMP Negeri 1 Mojokerto. ICISEI, 1(1), 183-191.

[12] Sudirjo, E. (2010). Model pembelajaran inovatif berbasis konsep sekolah ramah anak. Edu Humaniora Jurnal Pendidikan Dasar Kampus Cibiru, 2(1).

[13] Abduh, M., \& Zainudin, A. (2016). Role of Indonesian teachers' competencies in developing child friendly

[14] Oluremi, F. (2010). Creating a Friendly school Learning Environment for Nigerian Children European Scientific Journal, no.8, vol.8, 138147. 